\title{
AS CONTRIBUIÇÕES DA AMPLIAÇÃO DA UTILIZAÇÃO DO AMICUS CURIAE NO BRASIL PARA OS CASOS DE VIOLAÇÕES DE DIREITOS HUMANOS
}

\author{
Felipe José Nunes Rocha ${ }^{1}$
}

\section{Resumo:}

$\mathrm{O}$ artigo pretende, a partir de uma pesquisa bibliográfica e documental, analisar se o instituto do amicus curiae, que, com o advento do CPC de 2015, passou a poder ser utilizado em qualquer ação judicial e em qualquer grau de jurisdição, pode ser considerado um instrumento capaz de aprimorar as decisões judiciais domésticas relacionadas a questões de direitos humanos. Além de uma análise teórica acerca do amicus curiae, serão apresentadas decisões judiciais que revelam o potencial que a intervenção do amicus curiae tem de aprimorar o tratamento conferido pelo Poder Judiciário brasileiro aos casos de violações de direitos humanos.

Palavras-chave: amicus curiae; Código de Processo Civil; decisões judiciais; direitos humanos; Poder Judiciário

\section{THE CONTRIBUTIONS OF ENLARGING THE USE OF AMICUS CURIAE IN BRAZIL IN CASES OF HUMAN RIGHTS VIOLATIONS}

\begin{abstract}
:
The article intends, based on a bibliographic and documentary research, to analyze the institute of amicus curiae, which, with the advent of the CPC of 2015, started to be used in any legal action and in any degree of jurisdiction, can be considered an instrument able to improve domestic judicial decisions related to human rights issues. In addition to a theoretical analysis of amicus curiae, will be presented judicial judgments that reveal the potential for amicus curiae to improve the treatment of human rights violations by the Brazilian Judicial Power.
\end{abstract}

Keywords: amicus curiae; Civil Procedure Code; judicial decisions; human rights; Judicial Power

\section{INTRODUÇÃO}

Não são raros os casos de violação a direitos humanos no Brasil que não recebem a resposta adequada por parte do Estado Brasileiro através dos instrumentos jurídicos e das instituições do sistema de justiça pátrios.

\footnotetext{
${ }^{1}$ Advogado do escritório Macieira, Nunes, Zagallo \& Advogados Associados e professor universitário da Faculdade Estácio de São Luís-MA e do Centro Universitário Dom Bosco (UNDB). Graduado em Direito pela Universidade Federal do Maranhão, especialista em Direito Constitucional pela UNISUL e Mestre em Direito e Instituições do Sistema de Justiça pela Universidade Federal do Maranhão. E-mail: feliperocha7@ gmail.com.
} 
Diante disso, cada vez mais militantes e entidades que atuam na luta pela efetivação de direitos humanos têm tentado encontrar maneiras de aprimorá-la, recorrendo, inclusive, à instância internacional, através, por exemplo, do Sistema Interamericano de Direitos Humanos (SIDH), no qual o Brasil já foi, até o momento, oito vezes condenado através de sentenças Corte Interamericana de Direitos Humanos (CorteIDH) (RAMOS, 2018).

Por outro lado, o estudo acerca dos mecanismos nacionais e internacionais de combate às violações de direitos humanos também tem ganhado bastante destaque, através, por exemplo, dos estudos acadêmicos sobre o instituto do controle de convencionalidade, que passou a ser bastante estudado principalmente depois que o Supremo Tribunal Federal passou a reconhecer que todos os tratados internacionais de direitos humanos possuem uma hierarquia superior à da legislação infraconstitucional.

Entretanto, no que diz respeito ao campo judicial, o que se observa é que muitos magistrados parecem carecer de conhecimento técnico acerca do aparato normativo e institucional existente para prevenir e reprimir violações de direitos humanos ocorridas no Brasil.

Os exemplos que serão estudados neste trabalho para ilustrar a veracidade do que se afirmou acima dizem respeito a decisões judiciais, proferidas por magistrados do Poder Judiciário do Maranhão, acerca das medidas protetivas de urgência previstas na Lei Maria da Penha (SILVA; ROCHA, 2016) e de ações possessórias do município de Paço do Lumiar-MA (SILVA, 2018). Além disso, também serão analisadas decisões de tribunais brasileiros que colidem com a determinação da CorteIDH, contida na sentença proferida no caso Gomes Lund e outros vs. Brasil, de que o Judiciário brasileiro deixe de aplicar a Lei de Anistia em favor dos militares que praticaram crimes no período da ditadura militar (ROCHA, 2019).

A escolha dos exemplos supramencionados decorre do contato direto ou indireto que o autor deste artigo teve, ao longo de sua trajetória acadêmica e docente, com as decisões que serão analisadas e do seu interesse de possibilitar um maior impacto do trabalho sobre a realidade em que está inserido.

Por outro lado, especificamente no tocante às decisões que configuram um descumprimento ao dever imposto pela Corte Interamericana ao Judiciário brasileiro no caso Gomes Lund e outros Vs. Brasil, um outro fator que motivou a escolha foi a intenção do autor de chamar a atenção para a necessidade de se pensar em medidas pedagógicas que 
favoreçam a efetividade das decisões daquele tribunal internacional, através da superação dos obstáculos internos que têm sido apresentados.

Pois bem, considerando que o desconhecimento do Poder Judiciário pátrio compromete bastante o seu potencial de contribuir com o combate às violações de direitos humanos, faz-se importante que tanto as entidades que se especializam em litigância internacional quanto os profissionais e intelectuais que estudam o assunto desenvolvam práticas capazes de melhor familiarizar os Juízes, desembargadores e ministros com temas de direitos humanos, a fim de que essas matérias passem a ter um tratamento adequado por parte dos órgãos jurisdicionais.

Dentre várias outras iniciativas que poderiam surgir com este objetivo, pretende-se investigar, neste artigo, em que medida o instituto do amicus curiae - com a regulamentação prevista no Código de Processo Civil de 2015 (CPC/2015), que permite a sua utilização em qualquer ação judicial e qualquer grau de jurisdição - pode ser considerado um instrumento capaz de aprimorar as decisões judiciais domésticas relacionadas a temas de direitos humanos.

A relevância do tema decorre do fato do CPC/2015 ter passado a prever a possibilidade de qualquer juiz ou tribunal, de ofício ou mediante requerimento do interessado, solicitar ou admitir a participação de pessoa natural ou jurídica, órgão ou entidade especializada, com representatividade adequada, quando o julgamento tratar de matéria relevante ou de tema bastante específico ou quando a lide for de grande repercussão social (BRASIL, 2015).

Assim, pretende-se investigar, neste trabalho, a partir de uma pesquisa bibliográfica e documental, se a ampliação da utilização do amicus curiae trazida pelo CPC/2015 pode contribuir com o tratamento que o Poder Judiciário brasileiro confere aos casos que envolvem violações de direitos humanos.

Quanto à estruturação do artigo, em um primeiro momento, será feito um estudo acerca da figura do amicus curiae, a partir de seus elementos conceituais e de seu desenvolvimento no Direito Brasileiro e no âmbito do Sistema Interamericano de Direitos Humanos.

Em seguida, serão apresentados alguns dados relativos a decisões proferidas pelo Poder Judiciário maranhense relacionadas a medidas protetivas de urgência previstas na Lei Maria Penha, outros sobre decisões proferidas em ações possessórias, bem como sobre a resistência dos tribunais pátrios em deixar de aplicar a Lei de Anistia em favor dos militares. 
Dados esses que são capazes de ilustrar o quanto o desconhecimento e a falta de familiaridade dos magistrados com temas de direitos humanos têm comprometido a sua efetividade.

À medida que as decisões forem sendo apresentadas, será feita uma análise da viabilidade de se utilizar o amicus curiae para se superar, ou pelo menos reduzir, os obstáculos mencionados acima.

\section{O INSTITUTO DO AMICUS CURIAE NO ORDENAMENTO JURÍDICO BRASILEIRO E NO SISTEMA INTERAMERICANO DE DIREITOS HUMANOS}

Didier Junior conceitua o amicus curiae como sendo "o terceiro que, espontaneamente, a pedido da parte ou por provocação do órgão jurisdicional, intervém no processo para fornecer subsídios que possam aprimorar a qualidade da decisão" (2016, p.529).

Quanto à sua origem e ao seu desenvolvimento histórico, Bueno (2008) explica que, já no Direito Romano, havia a possibilidade do magistrado convocar um terceiro para lhe auxiliar no julgamento. Entretanto, foi no Direito inglês e no estadunidense - submetidos ao sistema do Common Law - que o instituto do amicus curiae efetivamente se desenvolveu, em razão, principalmente, do caráter vinculante dos precedentes, o qual tornava importante a permissão de que mesmo sujeitos que não eram partes do processo pudessem auxiliar a Corte, para evitar a formação de uma jurisprudência que pudesse vir a prejudicar inúmeras pessoas, em face do seu efeito erga omnes.

No Brasil, a primeira legislação a prever esse instituto, ainda que sem denominá-lo como tal, foi a Lei ${ }^{\circ}$ 6.616/1978, que alterou a redação do art. 31 da Lei $n^{\circ}$ 6.385/1976, o qual passou a prever que, nas ações judiciais cujo objeto corresponda a matéria de competência da Comissão de Valores Mobiliários (CVM), esta deverá sempre ser intimada para, caso queira, oferecer parecer ou prestar esclarecimentos (BUENO, 2008).

A partir de então, várias outras leis passaram a prever a possibilidade dessa forma anômala de intervenção de terceiro, sobretudo em casos que possam envolver um conhecimento técnico que não é razoável de se esperar que o magistrado possua.

Porém, as primeiras inovações que podem ser consideradas mais relevantes - por terem um aspecto mais abrangente - foram trazidas pela Lei $n^{\circ} 9.868 / 1999$, e pela Lei $n^{\circ}$ 9.882/1999. 
A primeira previu a possibilidade de intervenção do "amigo da Corte", nas ações de controle concentrado de constitucionalidade (BUENO, 2008), em seu art. $7^{\circ}, \S 2^{\circ}$ e no art. 20 , $\S 1^{\circ}$, cujo teor é o seguinte:

\begin{abstract}
Art. $7^{\circ}$ Não se admitirá intervenção de terceiros no processo de ação direta de inconstitucionalidade. [...]

$\S 2^{\circ} \mathrm{O}$ relator, considerando a relevância da matéria e a representatividade dos postulantes, poderá, por despacho irrecorrível, admitir, observado o prazo fixado no parágrafo anterior, a manifestação de outros órgãos ou entidades. [...]

Art. 20. [...]

$\S 1^{\circ}$ Em caso de necessidade de esclarecimento de matéria ou circunstância de fato ou de notória insuficiência das informações existentes nos autos, poderá o relator requisitar informações adicionais, designar perito ou comissão de peritos para que emita parecer sobre a questão ou fixar data para, em audiência pública, ouvir depoimentos de pessoas com experiência e autoridade na matéria. (BRASIL, 1999a) (sem grifos no original)
\end{abstract}

Em sentido semelhante, o art. $6^{\circ}, \S 1^{\circ}$ da Lei ${ }^{\circ} 9.882 / 1998$ previu a possibilidade do relator "requisitar informações adicionais, designar perito ou comissão de peritos para que emita parecer sobre a questão, ou ainda, fixar data para declarações, em audiência pública, de pessoas com experiência e autoridade na matéria" (BRASIL 1999b).

Posteriormente, também foi prevista a possibilidade de interessados se colaborarem com o Poder Judiciário, nos julgamentos dos temas de sua expertise, nos incidentes de uniformização de jurisprudência, no âmbito dos Juizados Especiais Federais (art.14, $§ 7^{\circ}$ da Lei $\mathrm{n}^{\circ}$ 10.259/2001), no procedimento para edição de súmulas vinculantes pelo Supremo Tribunal Federal (STF) (art. $3^{\circ}, 2^{\circ}$ da Lei $\left.n^{\circ} 11.417 / 2006\right)$ e para o debate sobre a repercussão geral dos recursos extraordinários e dos recursos especiais julgados pela sistemática dos recursos repetitivos (art.543-A, $\S 6^{\circ}$ e art.543-C, $\$ 4^{\circ}$ do Código de Processo Civil de 1973, inseridos pela Lei $n^{\circ} 11.418 / 2006$ e pela Lei $n^{\circ} 11.672 / 2008$, respectivamente) (BUENO, 2008).

Como se pode observar, a principal preocupação do legislador pátrio, até então, foi a de possibilitar a participação do amicus curiae naqueles julgamentos cujos efeitos não se restringiriam apenas às partes da lide, tornando-os presumivelmente relevantes para a sociedade como um todo. Essa configuração inicial se modificou, entretanto, com o advento do Código de Processo Civil de 2015, criado pela Lei $n^{\circ} 13.105 / 2015$, que passou a possibilitar a intervenção do amicus curiae em qualquer processo judicial e em qualquer grau de jurisdição, desde que a matéria demande conhecimento(s) específico(s), possua 
grande relevância ou que a lide seja de grande repercussão social, conforme prevê o seu art.138, cuja redação é a seguinte:

Art. 138. O juiz ou o relator, considerando a relevância da matéria, a especificidade do tema objeto da demanda ou a repercussão social da controvérsia, poderá, por decisão irrecorrível, de ofício ou a requerimento das partes ou de quem pretenda manifestar-se, solicitar ou admitir a participação de pessoa natural ou jurídica, órgão ou entidade especializada, com representatividade adequada, no prazo de 15 (quinze) dias de sua intimação.

$\S 1^{\circ} \mathrm{A}$ intervenção de que trata o caput não implica alteração de competência nem autoriza a interposição de recursos, ressalvadas a oposição de embargos de declaração e a hipótese do $\S 3^{\circ}$.

$\S 2^{\circ}$ Caberá ao juiz ou ao relator, na decisão que solicitar ou admitir a intervenção, definir os poderes do amicus curiae.

$\S 3^{\circ} \mathrm{O}$ amicus curiae pode recorrer da decisão que julgar o incidente de resolução de demandas repetitivas. (BRASIL, 2015)

O novo CPC, além de ser a primeira lei a mencionar expressamente o instituto do amicus curiae, também inovou ao possibilitar que as pessoas físicas atuem como tal, além das pessoas jurídicas, órgãos ou entidades especializadas que possuam representatividade adequada. Segundo Neves, a representatividade adequada seria a exigência de que:

[...] o terceiro demonstre ter um interesse institucional na causa, não sendo suficientes interesses meramente corporativos, que digam respeito somente ao terceiro que pretende ingressar na ação. Por interesse institucional compreende-se a possibilidade concreta do terceiro em contribuir com a qualidade da decisão a ser proferida, considerando-se que o terceiro tem grande experiência na área à qual a matéria discutida pertence. (2016, p.560)

Ademais, convém salientar que, apesar de, em regra, caber ao juiz ou ao relator a delimitação dos poderes do amicus curiae, como explica Didier Jr. (2016), é perfeitamente possível que o regimento interno de cada tribunal preveja determinadas prerrogativas ao mesmo, como, por exemplo, o regimento do STF, que prevê a possibilidade dele realizar sustentação oral no julgamento de ações de controle concentrado de constitucionalidade.

No mais, há que se acrescentar apenas que o regulamento da Corte Interamericana de Direitos Humanos também prevê a figura do amicus curiae nos julgamentos dos casos de violação de direitos humanos submetidos à jurisdição contenciosa da Corte, conforme previsão contida no artigo 44 da referida resolução, cujo teor é o segue:

Artigo 44. Apresentação de amicus curiae

1. O escrito de quem deseje atuar como amicus curiae poderá ser apresentado ao Tribunal, junto com seus anexos, através de qualquer dos meios estabelecidos no artigo 28.1 do presente Regulamento, no idioma de trabalho do caso, e com o nome do autor ou autores e assinatura de todos eles. 
2. Em caso de apresentação do escrito de amicus curiae por meios eletrônicos que não contenham a assinatura de quem o subscreve, ou no caso de escritos cujos anexos não os acompanhem, os originais e a documentação respectiva deverão ser recebidas no Tribunal num prazo de 7 dias contado a partir dessa apresentação. Se o escrito for apresentado fora desse prazo ou sem a documentação indicada, será arquivado sem mais tramitação.

3. Nos casos contenciosos, um escrito em caráter de amicus curiae poderá ser apresentado em qualquer momento do processo, porém no mais tardar até os 15 dias posteriores à celebração da audiência pública. Nos casos em que não se realize audiência pública, deverá ser remetido dentro dos 15 dias posteriores à resolução correspondente na qual se outorga prazo para o envio de alegações finais. Após consulta à Presidência, o escrito de amicus curiae, junto com seus anexos, será posto imediatamente em conhecimento das partes para sua informação.

4. Nos procedimentos de supervisão de cumprimento de sentenças e de medidas provisórias, poderão apresentar-se escritos de amicus curiae. (CORTEIDH, 2009, p.16)

Frise-se, aliás, que "[h]á casos notórios em que a intensa participação da sociedade civil gerou uma verdadeira legitimação do posicionamento adotado pela Corte" (MACHADO, 2012, p.284), a exemplo do caso Gomes Lund e outros Vs. Brasil, que será analisado no tópico seguinte.

\section{DECISÕES QUE EVIDENCIAM A PERTINÊNCIA DA INTERVENÇÃO DO AMICUS CURIAE EM CASOS DE VIOLAÇÕES DE DIREITOS HUMANOS}

Feitas estas considerações acerca do amicus curiae, passa-se a discorrer sobre casos emblemáticos que denotam o potencial que tal instituto tem para contribuir com o aprimoramento do tratamento que o Poder Judiciário brasileiro confere a situações que envolvem graves violações de direitos humanos.

\subsection{Decisões do Poder Judiciário maranhense relativas às medidas protetivas de urgência previstas na Lei Maria da Penha}

O estudo de decisões proferidas por instituições do Sistema de Justiça maranhense apresentam importantes evidências de que a efetividade dos instrumentos protetivos previstos na Lei $\mathrm{n}^{\mathrm{o}}$ 11.340/2006 tem sido comprometida por uma interpretação dos institutos eivada do ranço patriarcal e machista arraigado na cultura institucional do Poder Judiciário brasileiro

No presente artigo, serão analisadas seis decisões judiciais que dizem respeito a medidas protetivas de urgência previstas na Lei Maria da Penha, cuja finalidade é proteger as 
mulheres que estão em situação de risco real e iminente através de direitos concedidos à vítima e de uma série de deveres que podem ser impostos ao agressor, tais como a determinação de afastamento do lar, a proibição de aproximação da ofendida, dos familiares e das testemunhas e/ou de contato com os mesmos, bem como a proibição de frequentar determinados locais, a suspensão ou restrição do porte de armas, dentre outros (BRASIL, 2006).

A partir dessa sucinta exemplificação, já é possível perceber que as medidas protetivas de urgência constituem um importante mecanismo de proteção das mulheres sujeitas à violência doméstica, razão pela qual as decisões que extingam ou revoguem medidas já impostas requerem extrema cautela do magistrado, a fim de evitar que a mulher seja novamente colocada em situação de risco ou se mantenha nela dada à morosidade de deferimento ou prorrogação das mesmas. Entretanto, essa cautela não tem sido observada em vários casos de violência doméstica que tramitam no estado do Maranhão, conforme será visto a seguir.

Os primeiros casos a serem analisados correspondem aos Processos $n^{0}$ 63453.2014.8.10.0130 (MARANHÃO, 2015a) e 873-91.2013.8.10.0130 (MARANHÃO, 2015b), que dizem respeito a pedidos de aplicação de medidas protetivas de urgência que tramitaram na comarca de São Vicente Férrer-MA.

Em decisões publicadas no Diário de Justiça Eletrônico do Estado do Maranhão no dia 20 de agosto de 2015, o juiz da causa extinguiu os processos por considerar que teria havido perda superveniente do interesse de agir pelo simples fato de terem se passado mais de seis meses sem que tenham sido apresentadas quaisquer informações no sentido de que a violência persistiria. Transcreve-se abaixo o inteiro teor da sentença do primeiro caso acima mencionado, que é absolutamente idêntica à do seguinte, em sua fundamentação e dispositivo:

PROCESSO $\mathrm{N}^{\circ}$. 634-53.2014.8.10.0130 PEDIDO DE CONCESSÃO DE MEDIDAS PROTETIVAS DE URGÊNCIA Agressor: V. F. F, vulgo "Coelho" Vítima: M.A.C.F.

Sentença

M. A. C. F. requereu, através da autoridade policial, medida protetiva de urgência em face de V. F. F., vulgo "Coelho", ambos qualificados, alegando, em síntese, a ocorrência de ameaças pelo requerido. Decisão de deferimento das medidas protetivas de urgência às fls. 08/09. Cumprimento da medida protetiva às fls. $14 \mathrm{em}$ 14/07/14. Parecer do MPE pela extinção do feito às fls. 16, verso.

É o relatório. DECIDO.

No caso em apreço, foram deferidas em favor da requerente medidas protetivas de urgência. No entanto, passados mais de seis meses da sua efetivação, não há qualquer informação sobre a continuação de qualquer violência, o que faz concluir que a presente medida judicial não tem mais qualquer utilidade. $\mathrm{O}$ interesse de agir 
deve impedir o supérfluo e inútil apelo ao Judiciário e que falta a referida condição da ação quando o caminho pleiteado pelo interessado não é útil à satisfação de seu pedido. Na hipótese, cessando as ameaças, não há qualquer sentido na permanência da medida. Julgo, em consequiência, extinto o processo, com fundamento no art. 267, VI, do Código de Ritos. Sem custas P.R.I. Via edital, se necessário. Notifique-se o MP. Arquive-se oportunamente. [...] (MARANHÃO, 2015a).

É possível perceber, na presunção feita pelo juiz da causa, que o magistrado ignora o fato de que a violência doméstica contra a mulher está de tal maneira imbrincada na cultura patriarcal, que faz com que comumente a vítima seja envolvida em um ciclo de violência que tolhe a sua capacidade de seguir em frente com a busca pela punição do agressor e que a impele a manter a relação conjugal, ainda que a sua integridade física e psicológica estejam em risco. Sobre esse ciclo, Rocha explica que:

O recurso à violência nas relações íntimas ocorre de modo progressivo e constante, numa escalada que tende à cronificação e à rotinização, intensificando-se num ciclo que dificulta sua ruptura.[...]

A primeira fase, denominada "tensão do homem/medo da mulher", se caracteriza pela utilização de vários pretextos que funcionam como desencadeadores e justificadores da violência.[...]

A "agressão do homem/cólera ou tristeza da mulher" constitui a segunda fase, em que a explosão da violência ocorre, de modo cada vez mais agressivo e perigoso para a integridade física e psicológica da mulher, à medida que o ciclo se repete.

Segue-se a terceira fase, "desresponsabilização do homem/culpabilização da mulher", na qual o agressor tenta minimizar a gravidade de seu comportamento, justificá-lo devido a fatores exteriores, transferir para a companheira parte da responsabilidade pela violência em razão de seu comportamento ou lhe acusa de dramatizar a situação e de ter problemas mentais. Por sua vez, a mulher oculta sua cólera, interioriza a idéia de ser culpada pela violência e busca modificar suas atitudes e comportamentos visando resolver o problema.[...]

A última fase, "perdão do homem/esperança da mulher", também chamada de "luade-mel", na qual cessa a violência, há os pedidos de ajuda e desculpas, as promessas por parte do agressor, a oferta de presentes, a reconciliação. A mulher renova suas esperanças de mudança do companheiro, naquela fase, amável, carinhoso e calmo, e mantém a relação. Depois de algum tempo, quando o ciclo recomeça, a lembrança dessa fase dificulta que ela perceba os episódios de violência como parte desse círculo, como estratégia de controle e abuso de poder que a denigre. (2007a, p.6465)

Diante desse quadro, é preciso levar em consideração que, ainda que persista a situação de risco em que a mulher se encontrava quando solicitou as medidas protetivas, pode ser que ela deixe de voltar a se manifestar nos autos por passar por alguma das outras fases do ciclo de violência em que ela tende a achar que é um erro denunciar o agressor.

Assim, em razão da referida peculiaridade da situação de violência doméstica contra a mulher, o Poder Judiciário não deve dar aos processos judiciais que versem sobre tal questão o mesmo tratamento que é dirigido a causas que versam sobre Direito de Família, 
interpretando o silêncio da parte como perda do interesse processual ou como resolução da situação conflituosa, que ensejam a extinção do feito.

Considerando que é possível que a vítima tenha deixado de apresentar novas informações sobre agressões por medo, o que seria de se esperar é que o próprio Estado-juiz adotasse providências no sentido de esclarecer se a situação de violência efetivamente cessou, o que não ocorreu nos casos acima apresentados.

A própria Lei Maria da Penha traz, em seu artigo $4^{\circ}$, a recomendação de que "na interpretação desta Lei, serão considerados os fins sociais a que ela se destina e, especialmente, as condições peculiares das mulheres em situação de violência doméstica e familiar" (BRASIL, 2015).

$\mathrm{Na}$ verdade, o que se pode depreender do fato do juiz ter presumido a perda de interesse na manutenção das medidas protetivas de urgência, sem adotar qualquer providência no sentido de verificar in loco a situação das beneficiárias das medidas e sem sequer intimar as vítimas para que elas informassem se ainda persistia o interesse nas medidas, é um despreparo do magistrado para lidar adequadamente com o problema da violência doméstica contra a mulher.

Além disso, também se observa em tal postura a prevalência de uma cultura institucional que não dá a devida importância ao fenômeno da violência doméstica contra a mulher, conferindo-lhe um tratamento semelhante ao que é dado aos casos de Direito de Família, em que se busca a resolução do conflito através da pacificação e da manutenção das relações familiares.

Por outro lado, também é interessante que se faça a análise de quatro casos julgados pelo Tribunal de Justiça do Maranhão, que também dizem respeito a pedidos de medidas protetivas de urgência em que o juiz da Vara Especial de Violência Doméstica e Familiar contra a mulher da comarca de São Luís-MA considerou que teria havido a perda do interesse processual e extinguiu os processos em razão da ausência de manifestação da parte por um longo período.

Tratam-se dos seguintes processos: 1205-16.2011.8.10.0005, julgado em 19 de maio de 2015 pela Segunda Câmara Cível (MARANHÃO, 2015c); 630-08.2011.8.10.0005, julgado em 21 de outubro de 2014 pela Segunda Câmara Cível (MARANHÃO, 2014a), 29722.2012.8.10.0005, julgado em 23 de outubro de 2014 pela Terceira Câmara Cível (MARANHÃO, 2014b). 
Um primeiro ponto em relação aos referidos julgados que merece destaque é que todos eles foram proferidos após mais de um ano das datas em que foram prolatadas as sentenças que extinguiram as medidas protetivas de urgência, o que mostra que a extinção das medidas pode ter exposto as autoras a uma situação de vulnerabilidade por longo tempo.

Com efeito, é preciso muito empenho das instituições do Sistema de Justiça para modificar o quadro descrito por Almeida, que afirma que "a segurança da vítima não está no horizonte das instituições responsáveis, em tese, pela manutenção da ordem jurídico-social" e que a burocracia e morosidade da tramitação dos processos faz com que haja "tempo mais do que suficiente para que os conflitos recrudesçam e se transformem em crimes fatais" (1998, p.38).

Em segundo lugar, cumpre salientar que todos os acórdãos prolatados pelo Tribunal de Justiça do Maranhão nos casos sob análise foram no sentido de anular a sentença de primeira instância, que extinguiu as medidas protetivas de urgência em razão da ausência de manifestação das partes.

Entretanto, nos quatro casos acima mencionados, a fundamentação da decisão se baseou em argumentos estritamente formais, no sentido de que não teria sido efetuada a citação do representado e tampouco teria sido cumprida a exigência de que a autora seja intimada de todos os atos do processo e a informar se ainda tinha interesse na ação.

Diante disso, naqueles casos, não é possível saber se os desembargadores reconheceriam a necessidade de se dar um tratamento especial aos casos de violência doméstica contra a mulher, que não se prenda a formalismos que inviabilizem a efetividade dos instrumentos de proteção que a Lei Maria da Penha prevê.

Ante o quadro desolador acima exposto, percebe-se que a participação, na qualidade de amicus curiae, de entidades que militam em prol da igualdade de gênero e do combate à violência contra a mulher, ou mesmo de pesquisadoras(es) com profundo conhecimento acerca das peculiaridades da violência doméstica e familiar, através da apresentação de memoriais ou mesmo de sustentação oral em sessões de julgamento, poderia contribuir bastante para que os magistrados conferissem um tratamento mais adequado aos requerimentos de medidas protetivas de urgência.

\subsection{Decisões judiciais da comarca de Paço do Lumiar proferidas em ações possessórias}


Em sua monografia a respeito do desenvolvimento do instituto da posse no Direito brasileiro e do seu impacto sobre o tratamento conferido às ações possessórias coletivas pelo Poder Judiciário de Paço do Lumiar-MA, Silva (2018) chegou a importantes conclusões que denotam o quanto as decisões judiciais estudadas pelo autor se distanciam da concepção contemporânea do direito à posse e à propriedade. Como explica o autor:

\begin{abstract}
A pesquisa documental teve por base os processos de Reintegração de Posse de $n^{\circ}$ 3482013 (2 $2^{\mathrm{a}}$ Vara Cível) e 11112015 ( $1^{\mathrm{a}}$ Vara Cível), ajuizados em Paço do Lumiar/MA, em que se identificou a busca pela proteção do domínio pela via possessória, a ausência de alegação autoral no sentido de cumprimento da função social, bem como a presença de circunstâncias indicativas de inutilização/subutilização do imóvel. A partir desses casos concretos, a pesquisa demonstra que, em sua atuação, o Judiciário desconsidera a complexidade do conflito fundiário e utiliza conceitos de direito material e regras processuais já ultrapassadas no plano legislativo civil-constitucional atual em benefício do proprietário não possuidor. (SILVA, 2018, p.5. Sem grifos no original)
\end{abstract}

Com efeito, ao invés de analisar as normas relativas à proteção da posse a partir da exigência do cumprimento da função social da propriedade e do respeito a outros direitos fundamentais que encontram amparo constitucional, o Judiciário daquele município tem, segundo o autor, privilegiado uma visão conservadora e anacrônica do instituto da posse que se resume a tomar como parâmetro de análise as normas infraconstitucionais sobre o assunto. É o que se depreende dos seguintes fragmentos da conclusão do trabalho monográfico acima mencionado:

\begin{abstract}
A investigação dos casos concretos aqui realizada parece deixar cristalino que a atuação judicial não se resume ao puro e simples ato de aplicação do direito posto, mas da escolha de que direito aplicar, de que maneira e em favor de quem. Tanto que, como visto, casos semelhantes tiveram decisões completamente distintas, sendo que, na mais inquietante delas, deixou-se, convenientemente, de analisar concretamente o cumprimento ou não da função social, bem como o princípio da dignidade da pessoa humana invocados pelos réus - ambos de fundamento constitucional - simplesmente por se entender que a ocupação de propriedade alheia (no caso, um imenso terreno abandonado) constituiria ato ilícito - o que invalidaria a invocação daqueles argumentos pelos réus - quando, na verdade, o próprio abandono do imóvel retira do proprietário qualquer direito sobre o bem. [...]

É essa noção protecionista da propriedade desenvolvida durante todo o Séc. XX que, escorada na leitura conservadora da dogmática jurídica positivista, continua a ser refletida ainda hoje no Judiciário de Paço do Lumiar/MA, em clara resistência aos ideais progressistas de constitucionalização do direito, mesmo após bruscas alterações promovidas na disciplina civilista da posse.

Parece não haver espaço para a discussão de questões constitucionais que não estejam direta e expressamente tutelados no próprio diploma infraconstitucional. [...] (SILVA, 2018, p.58-59)
\end{abstract}

A partir da exposição perfunctória que foi feita das decisões judiciais relativas a ações possessórias de Paço do Lumiar-MA, já se torna possível perceber que a intervenção de 
profissionais, estudiosos ou militantes da luta pelo direito à terra, na qualidade de amicus(ci) curiae pode favorecer o aprimoramento do tratamento conferido pelo Judiciário do Maranhão às lides possessórias.

\subsection{Decisões judiciais que desrespeitam a determinação da CorteIDH contida na sentença do Caso Gomes Lund e outros Vs. Brasil acerca da Lei de Anistia}

O caso em questão faz remissão a um dos eventos mais graves de violação de direitos humanos da Ditadura Militar brasileira, que foi a chamada "Guerrilha do Araguaia", em que 750 militares receberam ordens de executar sumariamente 71 guerrilheiros (MEYER, 2013).

Ante a ausência de informações acerca do paradeiro dos militantes desaparecidos na região, situada no estado do Pará, os familiares de 61 guerrilheiros procuraram o Poder Judiciário brasileiro, mas, por não obterem êxito, recorreram à Comissão Interamericana em 7 de agosto de 1995, através de entidades como o Centro pela Justiça e o Direito Internacional (CEJIL), o Human Rights Watch/Americas, o Grupo Tortura Nunca Mais do Rio de Janeiro e a Comissão de Familiares de Mortos e Desaparecidos Políticos do Instituto de Estudos da Violência do Estado da Universidade de São Paulo (MEYER, 2013).

Em 29 de março de 2009, a Comissão Interamericana submeteu o caso à Corte Interamericana de Direitos Humanos, que prolatou sentença em 24 de novembro de 2010 (MEYER, 2013). Na referida decisão, a Corte considerou que o Brasil violou vários dispositivos da Convenção Americana de Direitos Humanos e lhe impôs várias condenações, dentre as quais, encontram-se as seguintes:

[...] a) O Estado brasileiro deverá proceder a uma investigação judicial completa, efetiva e imparcial dos desaparecimentos forçados, identificando os responsáveis e sancionando-os criminalmente. A CteIDH estabeleceu que esses crimes são imprescritíveis e não podem ser objeto de anistias. Além disto, tais responsabilizações deverão acontecer no foro civil e não no foro militar. [...] (MEYER, 2013, p.222-223)

Ainda a respeito da referida condenação, também é importante salientar que, naquela sentença, a Corte Interamericana consignou expressamente que, apesar de o Supremo Tribunal Federal ter considerado que a Lei de Anistia (Lei no 6.683 de 1979) também serviria para anistiar os crimes praticados pelos militares no período da Ditadura Militar, tal entendimento não poderia constituir um óbice para que os militares responsáveis pelo desaparecimento forçado das vítimas da Guerrilha do Araguaia fossem processados e punidos,

Rev. de Direitos Humanos em Perspectiva | e-ISSN: 2526-0197 | Evento Virtual | v. 6 | n. 1 | 
tendo em vista que tal interpretação da Lei de Anistia configurava violação a vários compromissos internacionais assumidos pelo Brasil (CORTEIDH, 2010).

Por outro lado, a Corte também afastou o entendimento no sentido de que a punição dos crimes cometidos no período da Ditadura militar implicaria em violação ao princípio da irretroatividade da lei penal, por entender que o desaparecimento forçado é um delito que possui natureza contínua e permanente (CORTEIDH, 2010).

Com base em tais fundamentos, é que a Corte Interamericana, ao discorrer sobre o dever do Estado brasileiro de investigar e punir os crimes discutidos no caso Gomes Lund e outros Vs. Brasil, previu a obrigação do Brasil de:

\begin{abstract}
[...] determinar os autores materiais e intelectuais do desaparecimento forçado das vítimas e da execução extrajudicial. Ademais, por se tratar de violações graves de direitos humanos, e considerando a natureza dos fatos e o caráter continuado ou permanente do desaparecimento forçado, o Estado não poderá aplicar a Lei de Anistia em benefício dos autores, bem como nenhuma outra disposição análoga, prescrição, irretroatividade da lei penal, coisa julgada, ne bis in idem ou qualquer excludente similar de responsabilidade para eximir-se dessa obrigação [...]. (CORTEIDH, 2010, p.96, sem grifos no original)
\end{abstract}

Entretanto, embora o Ministério Público Federal tenha desempenhado um papel muito importante para dar cumprimento à sentença, promovendo uma série de denúncias contra militares que praticaram crimes no período da Ditadura Militar, o que se observa é que o Poder Judiciário brasileiro tem manifestado uma grande resistência em acatar o que restou decidido pela Corte.

No presente trabalho, serão analisadas apenas as três denúncias ofertadas pelo MPF (MARX, 2015) que versam sobre crimes cometidos na Guerrilha do Araguaia, por serem as que se relacionam mais diretamente com os fatos discutidos no caso Gomes Lund e outros Vs. Brasil.

Quanto à primeira denúncia, feita contra Sebastião Curió Rodrigues de Moura na Justiça Federal de Marabá-PA, é útil apresentar a síntese do seu desfecho feita por Marx, nos termos seguintes:

[...] A defesa do acusado, em 30/10/2012, impetrou o Habeas Corpus $n^{\circ} 0068063$ 92.2012.4.01.0000, junto ao TRF da $1^{\text {a }}$ Região, objetivando o trancamento da ação penal. Medida liminar determinando a suspensão do processo até o juízo final de mérito do Habeas Corpus foi concedida em 19 de novembro. Em 18 de novembro de 2013, a $4^{\text {a }}$ Turma do TRF da $1^{\text {a }}$ Região, por maioria, concedeu ordem para trancar a ação penal. O MPF ingressou com embargos de declaração, rejeitados em 15 de julho de 2014. Recursos especial e extraordinário foram interpostos pelo MPF. $(2015$, p.460-461) 
Na segunda (Processo $\mathrm{n}^{\circ}$ 0004334-29.2012.4.01.3901²), oferecida em 16 de julho de 2012, o MPF denunciou Lício Augusto Maciel por sequestro qualificado por maus-tratos em razão do desparecimento forçado de Divino Ferreira de Souza, ocorrido em 14 de outubro de 1973 (MARX, 2015).

A referida denúncia teve andamento bastante semelhante à primeira: foi recebida em primeira instância, mas, após o ajuizamento de habeas corpus pelo acusado (Processo $\mathrm{n}^{\mathrm{o}}$ 0066237-94.2013.4.01.0000), foi concedida liminar (BRASIL, 2019a) determinando o trancamento da ação penal pelo mesmo desembargador do Tribunal Regional Federal da $1^{\mathrm{a}}$ Região, através de decisão com idêntico teor ao da que foi prolatada no caso de Sebastião Curió (BRASIL, 2019a), estando ambos os casos aguardando julgamento do Superior Tribunal de Justiça e do Supremo Tribunal Federal.

Com efeito, em ambas as situações o desembargador federal Olindo Menezes determinou liminarmente o trancamento das ações penais, por considerar que a sentença do caso Gomes Lund e outros Vs. Brasil não prevaleceria sobre o entendimento do STF no sentido de que a Lei de Anistia também se aplicaria sobre os crimes praticados pelos militares na época da ditadura militar (BRASIL, 2016b).

Vê-se, portanto, que embora aquele magistrado tivesse ciência da sentença da Corte Interamericana, descumpriu deliberadamente a parte da decisão que aduz que "o Estado não poderá aplicar a Lei de Anistia em benefício dos autores, bem como nenhuma outra disposição análoga, prescrição, irretroatividade da lei penal, coisa julgada, ne bis in idem" (CORTEIDH, 2010, p.96), em claro desrespeito à autoridade daquele tribunal internacional.

Aliás, a própria CorteIDH, em uma resolução relativa à supervisão do cumprimento da sentença, de outubro de 2014, manifesta a sua reprovação à conduta do Judiciário brasileiro de descumprir a decisão, ao se pronunciar sobre o Processo nº068063-92.2012.4.01.0000, como se vê nas seguintes passagens daquele documento:

\begin{abstract}
[...] De acordo com o Direito Internacional, que foi soberanamente aceito pelo Estado, é inaceitável que uma vez que a Corte Interamericana tenha proferido uma Sentença o direito interno ou suas autoridades pretendam deixá-la sem efeitos. Portanto, o Brasil não pode opor decisões adotadas no âmbito interno como justificativa de seu descumprimento da sentença proferida por este tribunal internacional de direitos humanos, nem sequer quando tais decisões provenham do tribunal da mais alta hierarquia no ordenamento jurídico nacional. [...] (CORTEIDH, 2014, p.10-12, sem grifos no original)
\end{abstract}

\footnotetext{
${ }^{2}$ Após o recebimento da denúncia, a ação penal adquiriu o número 0006232-77.2012.4.01.3901 (BRASIL, 2019b).
} 
Mas, em vez do Estado brasileiro mudar de postura após a Corte Interamericana ter chamado a sua atenção para a necessidade de as decisões judiciais se adequarem ao entendimento consagrado na sentença que julgou o caso Gomes Lund e outros Vs. Brasil, verifica-se que a resistência acima demonstrada persistiu, o que pode ser comprovado pelo fato da terceira denúncia do MPF relativa a crimes da Guerrilha do Araguaia, oferecida em 28 de janeiro de 2015, não ter sido recebida pelo juiz federal de primeira instância da subseção judiciária de Marabá-PA (BRASIL, 2019c).

Assim, o que se verifica é que, em vez de perceberem a Corte Interamericana de Direitos Humanos como uma instância jurisdicional cuja autoridade deve prevalecer sobre a das instituições do sistema de justiça domésticas - inclusive sobre a do Supremo Tribunal Federal -, os magistrados brasileiros têm desobedecido deliberadamente os deveres jurídicos que lhes foram impostos pela sentença de Corte Interamericana por entenderem que a decisão do STF deve prevalecer sobre a daquele tribunal internacional, comprometendo sensivelmente a efetividade do sistema interamericano de direitos humanos.

Por outro lado, o fato de, em 2018, o Brasil ter sido novamente condenado pela CorteIDH, em sentença proferida no caso Vladimir Herzog e outros Vs. Brasil, por ter deixado de investigar, processar e punir os algozes da vítima, assassinada por militares na época da Ditadura Militar (ROCHA, 2019), de, até o momento, o Supremo Tribunal Federal não ter julgado os Embargos de Declaração opostos pelo Conselho Federal da OAB nos autos da ADPF $n^{\circ} 153$ e a ADPF $n^{\circ} 320$, proposta pelo PSOL também com o intuito de provocar aquele tribunal a se pronunciar sobre as determinações contidas na sentença do caso Gomes Lund e outros Vs. Brasil (ROCHA, 2019), em que pese a veemência com que a CorteIDH reiterou, ainda em outubro de 2014, o dever do Estado brasileiro de cumprir a sentença e de modificar a interpretação que foi conferida à Lei de Anistia (CORTEIDH, 2014), demonstra o quanto o funcionamento do SIDH tem sido prejudicado pela atuação do Judiciário brasileiro.

Dito isto, já se torna possível perceber o quão importante é que as entidades que militam em prol da justiça de transição solicitem dos órgãos do Poder Judiciário brasileiro a sua habilitação como amicus curiae nos processos penais que discutam a responsabilidade penal dos militares pelos crimes praticados na ditadura militar, para tentar provocar uma mudança de postura dos magistrados e dos tribunais no sentido de viabilizar a punição dos acusados. 
Entretanto, é necessário tecer breves considerações sobre a possibilidade de se utilizar tal instituto na esfera penal, já que o Código de Processo Penal (CPP) não menciona expressamente tal possibilidade e que as normas que permitem essa utilização em qualquer instância estão previstas no Código de Processo Civil, não se aplicando, em tese, às ações penais.

A esse respeito, insta salientar, a princípio, que, embora não haja expressa autorização da utilização do instituto em âmbito criminal, pode-se aplicar as normas do CPC, por analogia, aos processos penais, em virtude do disposto no art. $3^{\circ}$ do CPP, que aduz que “[a] lei processual penal admitirá interpretação extensiva e aplicação analógica, bem como o suplemento dos princípios gerais de direito" (BRASIL, 1941).

De fato, o Superior Tribunal de Justiça já se posicionou quanto a essa possibilidade em uma decisão monocrática proferida no Recurso Especial no 1.563 .962 - RN que, embora tenha negado o pedido de habilitação dos postulantes, afirmou expressamente que é viável a habilitação de amici curiae em tais feitos, como se vê abaixo:

Trata-se de petição protocolizada, às e-STJ fls. 308/313, pelo Ministério Público do Estado de Alagoas, na qual pugna pela sua admissão no presente processo como amicus curiae, com fundamento no art. 138 do Código de Processo Civil c/c o art. $3^{\circ}$ do Código de Processo Penal. [...] Nesse contexto, embora se revele possível a intervenção do amicus curiae também no processo penal, por meio de aplicação analógica expressamente autorizada pelo art. $3^{\circ}$ do Código de Processo Penal, deve-se analisar sua utilidade sem se descurar da necessidade de manutenção da paridade de armas, sob pena de se agravar a situação processual do réu. (BRASIL, 2019 c, sem grifos no original)

Vê-se, portanto, que é perfeitamente cabível e recomendável a intervenção de amici curiae em lides que digam respeito ao (des)cumprimento de obrigações impostas ao Brasil por tratados ou entidades internacionais, como a CorteIDH, sendo útil observar que os próprios órgãos do SIDH (a CIDH ou a Corte Interamericana, por exemplo) ou organizações não governamentais especializadas em litigância internacional - a exemplo da ONG "Justiça Global" (ROCHA, 2019) - poderiam fornecer importantes subsídios para os julgamentos, em casos dessa natureza.

\section{CONCLUSÃO}

Ao longo do presente artigo, observou-se que, apesar de, juridicamente, o Brasil ter o dever de cumprir os direitos humanos previstos na Constituição Federal, na legislação 
infraconstitucional pátria e nos tratados internacionais que assina, por uma série de motivos e em diversas situações, o Poder Judiciário deste país não tem lidado adequadamente com demandas que envolvem graves violações de direitos humanos.

Neste contexto, o instituto do amicus curiae se apresenta como uma espécie de intervenção de terceiro nos processos judiciais que pode fornecer importantes subsídios de ordem técnica e prática para os magistrados que precisam lidar com os casos de graves violações de direitos humanos.

De fato, a análise das decisões judiciais estudadas neste trabalho revela que a ausência de conhecimento e de sensibilidade dos juízes e dos tribunais acerca da complexidade e das peculiaridades que envolvem as ações que versam sobre a efetivação dos direitos humanos de setores historicamente oprimidos na sociedade prejudica bastante o exercício do dever que as instituições do sistema de justiça têm de assegurar esses direitos, quando violados por particulares ou pelos próprios agentes do Estado.

Assim, a possibilidade de pessoas com expertise e/ou experiência de militância e entidades com profundo conhecimento teórico e prático se manifestarem, em qualquer grau de jurisdição, conforme aduz o CPC/2015, em ações relacionadas a assuntos que, na melhor das hipóteses, são estudados apenas superficialmente nos cursos de Direito, por certo, tem muito a contribuir para que os magistrados que as julgam abordem tais temas de forma adequada.

Além disso, o fato do Código de Processo Civil permitir que a iniciativa da intervenção do amicus curiae se dê de ofício ou por requerimento das partes pode fazer com que as decisões gozem de maior legitimidade, por possibilitar que, pelo menos em tese, vozes da sociedade civil que costumam ser silenciadas em conflitos que envolvem direitos humanos apresentem o seu ponto de vista.

Enquanto isto não ocorrer, os importantes avanços em matéria de direitos humanos que a litigância nacional e internacional tem trazido para o Brasil continuarão sofrendo sérias restrições decorrentes de uma cultura institucional anacrônica e incompatível com a configuração do cenário jurídico, político e social hodierno.

\section{REFERÊNCIAS}

BRASIL. Lei no 13.105, de 16 de março de 2015. Código de Processo Civil. Disponível em: < http://www.planalto.gov.br/ccivil_03/_ato2015-2018/2015/lei/113105.htm>. Acesso em 10 mar. 2019. 
BRASIL. Lei $\mathbf{n}^{\circ}$ 9.868, de 10 de novembro de 1999a.

Dispõe sobre o processo e julgamento da ação direta de inconstitucionalidade e da ação declaratória de constitucionalidade perante o Supremo Tribunal Federal.

Disponível em: < http://www.planalto.gov.br/ccivil_03/leis/L9868.htm>. Acesso em: 10 mar. 2019.

BRASIL. Lei n⿳0 9.882, de 3 de dezembro de 1999b.

Dispõe sobre o processo e julgamento da argüição de descumprimento de preceito

fundamental, nos termos do $\S 1^{\circ}$ do art. 102 da Constituição Federal.

Disponível em: < http://www.planalto.gov.br/ccivil_03/leis/L9882.htm>.

Acesso em: 10 mar. 2019.

BRASIL. Lei $\mathbf{n}^{\mathbf{0}}$ 11.340, de 7 de agosto de 2006. Cria mecanismos para coibir a violência doméstica e familiar contra a mulher, nos termos do $\S 80$ do art. 226 da Constituição Federal, da Convenção sobre a Eliminação de Todas as Formas de Discriminação contra as Mulheres e da Convenção Interamericana para Prevenir, Punir e Erradicar a Violência contra a Mulher; dispõe sobre a criação dos Juizados de Violência Doméstica e Familiar contra a Mulher; altera o Código de Processo Penal, o Código Penal e a Lei de Execução Penal; e dá outras providências. Disponível em <http://www.planalto.gov.br/CCIVIL/_Ato20042006/2006/Lei/L11340.htm>. Acesso em 20 mar.2019.

BRASIL. Tribunal Regional Federal da $1^{\text {a }}$ Região. Habeas corpus $\mathbf{n}^{\mathbf{0}} 0066237$ -

94.2013.4.01.0000. Impetrante: Rodrigo Henrique Roca Pires. Impetrado: Juiz federal da $2^{\mathrm{a}}$ vara da subseção judiciária de Marabá - PA. Paciente: Lício Augusto Maciel. Relator: Olindo de Menezes. Brasília, 5 de novembro de 2013. Disponível em: <www.stj.jus.br>. Acesso em: 30 abr. 2019a.

BRASIL. Tribunal Regional Federal da $1^{\text {a }}$ Região. Habeas corpus $\mathbf{n}^{\mathbf{0}} \mathbf{0 0 6 8 0 6 3 -}$ 92.2012.4.01.0000. Impetrante: Mário Gilberto de Oliveira. Impetrado: Juiz federal da $1^{\mathrm{a}}$ vara da subseção judiciária de Marabá - PA. Paciente: Sebastião Curió Rodrigues de Moura. Relator: Olindo de Menezes. Brasília, 30 de outubro de 2012. Disponível em: <www.stj.jus.br>. Acesso em: 30 abr. 2019b.

BRASIL. 1 $1^{\text {a }}$ Vara Federal da Subseção judiciária de Marabá-PA. Denúncia $\mathbf{n}^{0}$ 000034255.2015.4.01.3901. Autor: Ministério Público Federal. Réus: Sebastião Curió Rodrigues de Moura e Lício Augusto Ribeiro Maciel. Juiz federal: Marcelo Honorato. Brasília, 29 de janeiro de 2015. Disponível em: <www.trf1.jus.br>. Acesso em: 30 abr. 2019c.

BRASIL. Decreto-lei $n^{0}$ 3.689, de 3 de outubro de 1941. Código de Processo Penal. Disponível em:

<http://www.planalto.gov.br/ccivil_03/decreto-lei/Del3689compilado.htm>. Acesso em: 30 abr. 2019.

BRASIL. Superior Tribunal de Justiça. Recurso Especial no 1.563.962 - RN. Recorrente: Ministério Público do Estado do Rio Grande do Norte. Recorrido: E. A. Relator: Ministro Reynaldo Soares da Fonseca. Brasília, 30 de setembro de 2016. Disponível em: <www.stj.jus.br>. Acesso em: 30 abr. 2019c.

Rev. de Direitos Humanos em Perspectiva | e-ISSN: 2526-0197 | Evento Virtual | v. 6 | n. 1 | 
BUENO, Cassio Scarpinella. Amicus curiae no processo civil brasileiro: um terceiro enigmático. 2. ed. São Paulo: Saraiva, 2008.

CORTEIDH. Regulamento da Corte Interamericana de Direitos Humanos. Aprovado pela Corte no seu LXXXV Período Ordinário de Sessões celebrado de 16 a 28 de novembro de 2009.

Disponível em: <http://www.corteidh.or.cr/sitios/reglamento/nov_2009_por.pdf>. Acesso em 10 mar. 2019.

CORTEIDH.Caso Gomes Lund e outros ("Guerrilha do Araguaia") Versus Brasil: sentença de 24 de novembro de 2010. Disponível em:

<www.corteidh.or.cr/docs/casos/articulos/seriec_219_por.pdf>. Acesso em 30 abr. 2019.

CORTEIDH. Resolução da Corte Interamericana de Direitos Humanos de 17 de outubro de 2014. Caso Gomes Lund e outros ("Guerrilha do Araguaia") Vs. Brasil: Supervisão de cumprimento de sentença. Disponível em:

<www.corteidh.or.cr/docs/supervisiones/gomes_17_10_14_por.pdf >. Acesso em 30 abr. 2019.

DIDIER JUNIOR, Fredie. Curso de direito processual civil: introdução ao direito processual civil, parte geral e processo de conhecimento. 18 ed. v.1. Salvador: Jus Podivm, 2016.

MACHADO, Isabel Penido de Campos. Sistema Interamericano de Proteção dos Direitos Humanos: Comissão e Corte Interamericana de Direitos Humanos. In: OLIVEIRA, Bárbara da Costa Pinto; SILVA, Roberto Luiz (org.). Manual de Direito Processual Internacional. São Paulo : Saraiva, 2012.

MARANHÃO. Tribunal de Justiça do Maranhão. Sentença do Processo $n^{\circ}$ 63453.2014.8.10.0130. Juiz de Direito da comarca de São Vicente Férrer/MA Karlos Alberto Ribeiro Mota. Diário de Justiça do estado do Maranhão. 20 ago. 2015a. p.1084

MARANHÃO. Tribunal de Justiça do Maranhão. Sentença do Processo no ${ }^{\circ}$ 87391.2013.8.10.0130. Juiz de Direito da comarca de São Vicente Férrer/MA Karlos Alberto Ribeiro Mota. Diário de Justiça do estado do Maranhão. 20 ago. 2015b. p. 1084.

MARANHÃO. Tribunal de Justiça do Maranhão. Acórdão da Apelação Cível no 63008.2011.8.10.0005. Relator: Desembargador Marcelo Carvalho Silva. Diário de Justiça do estado do Maranhão. 24 out. 2014a. p.74-75.

MARANHÃO. Tribunal de Justiça do Maranhão. Acórdão da Apelação Cível no 297 22.2012.8.10.0005. Relator: Desembargador Lourival de Jesus Serejo Sousa. Diário de Justiça do estado do Maranhão. 30 out. 2014b. p.98.

MARANHÃO. Tribunal de Justiça do Maranhão. Acórdão da Apelação Cível $\mathrm{n}^{\circ}$ 120516.2011.8.10.0005. Relator: Desembargador Marcelo Carvalho Silva. Diário de Justiça do estado do Maranhão. 8 jun. 2015c. p.103-104. 
MARX, Ivan Cláudio. Atuação do Ministério Público Federal na Justiça Transicional brasileira. In: SOUSA JUNIOR, José Geraldo de. et. al. (orgs.). O direito achado na rua: introdução crítica à justiça de transição na América Latina. v.7. 1. ed. Brasília: UnB, 2015. Disponível em: <http://www.justica.gov.br/central-de-conteudo/anistia/anexos/15-12-15direito-achado-na-rua-vol-7_web-versao-10mb-1.pdf >. Acesso em 30 abr. 2019.

MEYER, Emílio Peluso Neder. Responsabilização por graves violações de direitos humanos na ditadura de 1964-1985: a necessária superação da decisão do Supremo Tribunal Federal na ADPF n ${ }^{\circ}$ 153/DF pelo Direito Internacional dos Direitos Humanos. Tese de Doutorado. Belo Horizonte: UFMG, 2013. Disponível em:

<https://www.ufmg.br/online/arquivos/anexos/emilio_peluso_neder_meyer.pdf> Acesso em: 30 abr. 2019.

NEVES, Daniel Amorim Assumpção. Manual de direito processual civil. Vol. Único. 8. ed. Salvador: Ed. JusPodivm, 2016.

ROCHA, Felipe José Nunes. Direitos humanos e justiça de transição: Obstáculos para o cumprimento da sentença do caso Gomes Lund e outros Vs. Brasil. Curitiba: Juruá, 2019.

SILVA, Daniel Viana. Alterações na noção de posse no Direito brasileiro e seus reflexos nos conflitos fundiários coletivos judicializados no município de Paço do Lumiar/MA. São Luís: Monografia, Centro Universitário Dom Bosco - UNDB, 2018.

RAMOS, André de Carvalho. Curso de Direitos Humanos. 5. ed., São Paulo: Saraiva Educação, 2018.

SILVA, Artenira Silva e; ROCHA, Felipe José Nunes. Violência institucional como obstáculo para a efetividade da Lei Maria da Penha: um estudo a partir de decisões do Judiciário maranhense. In: SILVA, Artenira Silva e; MANSO, Almudena Garcia. (Org.). A aplicação da Lei Maria da Penha no Maranhão. 1ed. São Luís-MA: EDUFMA, 2016, v. 1, p. 49-84. 